Original articles

J. Perinat. Med.

2 (1974) 17

\title{
Effects of sympathomimetic tocolytic agents on the fetus
}

\section{Volker Unbehaun}

Universitäts-Frauenklinik Tübingen

Received March 5, 1973. Accepted July 1, 1973.

The variety of factors controlling the onset of parturition, as well as the very complex mechanisms which physiologically maintain pregnancy by inhibiting uterine contractions are only partially understood today. As long as the triggering mechanisms, and the conditions favoring timely and early labor are incompletely known, symptomatic therapeutic attempts aim at blocking unwanted contractile activity of the uterine smooth muscle fibres. The high rates of neonatal mortality and morbidity associated with premature births [52] have stimulated efforts to find agents which safely inhibit uterine contractions in humans.

\section{Inhibition of uterine activity by $\beta$-mimetic agents}

A theoretic basis has been provided by AHLQUIST's [2] concept of adrenergic $\alpha$ - and $\beta$ receptors, which can also be applied to the pregnant uterus $[3,18,19]$ : Stimulation of the myometrial $\beta$-adrenergic receptors causes relaxation of the uterine muscle in pregnancy. Since the 1960 's a series of $\beta$-mimetic uterusinhibiting catecholamine derivatives have been synthesized and tested. Their chemical constitutions, the basic theoretic considerations for their clinical use, and the increasingly successful use in the treatment and the management of premature and excessive labor have been reviewed recently $[19,20,29,30,32,42,75]$. The most frequently used compounds are: Isoxsuprine $=$ Duvadilan, Vasodilan; Ritodrine $=\mathrm{Du} 21220$; Buphenin = Nylidrin, Dilatol; TV 399; Th 1165a.

The dose-dependent inhibition of uterine contractions and suppression of intra-amniotic pres-

\section{Curriculum vitae}

Volker UNBEHAUN: Born Maj' 24, 1933 in Giessen. Medical education in Frankfurt/M., Mainz, Tubingen, Hamburg and Giessen. 1958 to 1959 Patbological Institute of the University of Giessen. Following graduation, from 1960-1962, Pbysiological \& Chemical Institute of the University of Mainz.

Papers on effects of aluminum

and metabolism of xylit. Since 1962 at University Gynaecological Clinic at Tübingen. Papers on the activities of enzymes, especially catabolic enzymes in the corpus luteum, also about the reaction of enzyme activities to pregnancy and labour, as well as metabolic changes during tocolytic therapy. Assistant Professor 1970, and since then Associate Professor (Oberarzt).

sure in vivo have been demonstrated recently [35].

In Tab. I some clinical results in the treatment of premature labor are summarized.

In spite of the wide application of adrenergic $\beta$-mimetic agents to inhibit premature labor, the fetalneonatal effects of the compounds used have been rather poorly evaluated in the past.

\section{The complex of the $\beta$-stimulated res- ponse}

An approach to the evaluation of the possible influences of tocolytic catecholamine derivatives on the fetus has to start from the fact that the relaxation of uterine smooth muscle is only one component of the $\beta$-stimulated response. The spectrum of effects triggered off by the $\beta$-adrenergic stimulus additionally consists of cardio vascular and metabolic reactions [24]. 
Tab. I. Clinical results of $\beta$-mimetic therapy for the prevention of premature births.

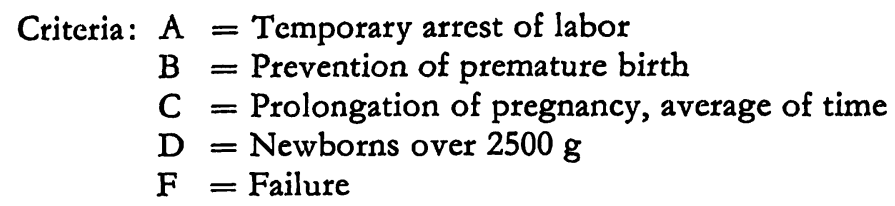

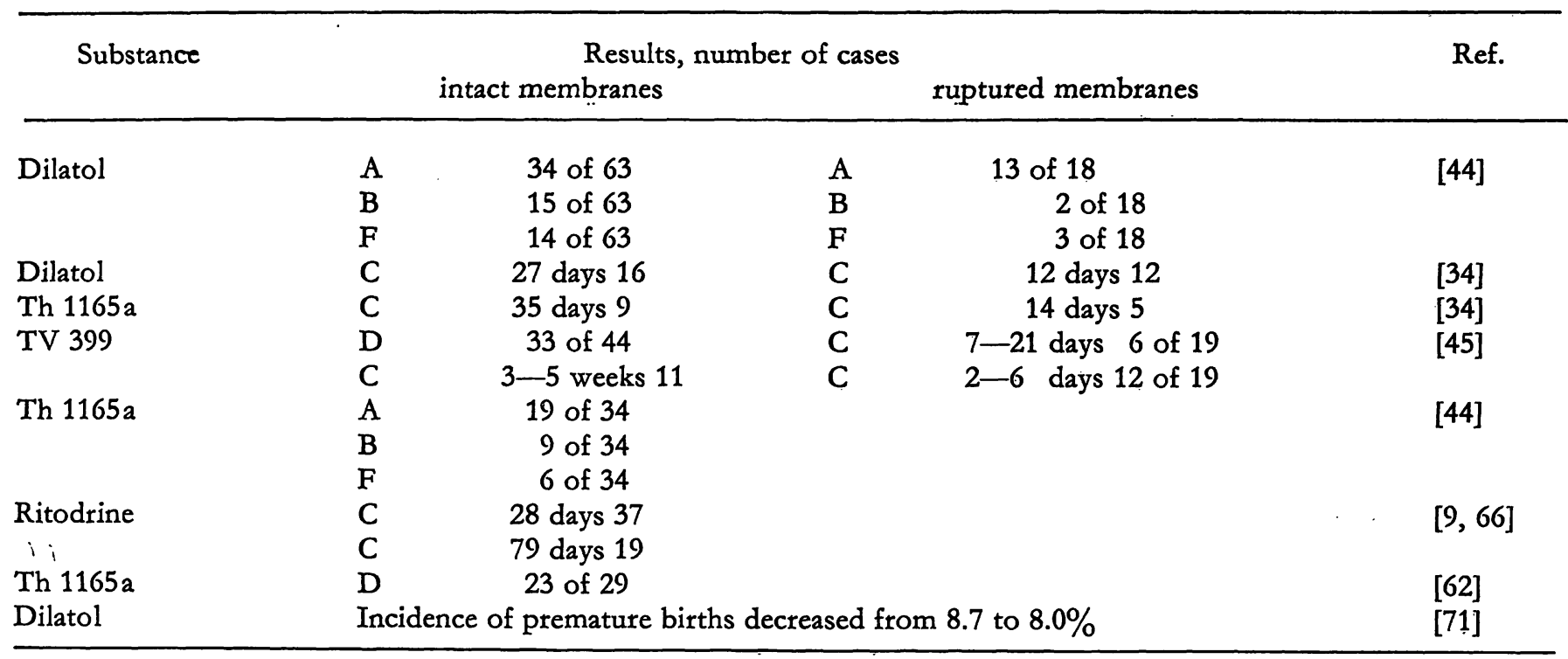

\section{A) Cardiovascular reactions:}

1. Positive chronotropic and positive inotropic stimulation of the myocardium cause tachycardia.

2. Vasodilatation increases the peripheral bloodflow.

3. Systolic and diastolic hypotonia.

B) Metabolic reactions: Stimulation of the cell membrane enzyme adenyl cyclase, which catalyzes the intracellular formation of cyclic 3'5'-adenosine monophosphate from adenosine triphosphate. Cyclic 3'5'-AMP catalyzes the activation of:

1. Glycogen phosphorylase

2. Lipase.

Glycogenolysis and lipolysis are estbalished $\beta$ mimetic effects, and result in marked changes in intra- and extracellular concentrations of carbohydrate- and fat metabolites.

The evaluation of possible fetal-neonatal influences of tocolytic catecholamine derivatives has to take into consideration the whole pattern of $\beta$-stimulated responses.

\section{Influence upon the fetus, and possibilities of evaluating these effects}

The fetal organism may be involved in two ways, which may act in conjunction:

A) 1. Maternal cardiovascular reactions to $\beta$-mimetic drugs influence the utero-placental and fetal circulation.

2. According to the level of maternal concentrations, carbohydrate- and fat metabolites are increasingly transferred accross the placenta causing alterations of the fetal metabolic homeostasis.

B) The tocolytic substances are readily transferred across the placenta and induce the complete typical pattern of $\beta$-stimulated responses in the fetal organism itself.

In contrast to the mother, the fetus is generally not accessible for assays of metabolism. Successful administration of tocolytics with inhibition of premature labor and advancement of parturition almost exclude availability of the fetus and newborn to direct investigations of biochemical parameters. Studies of the fetal situation during tocolytic therapy are therefore mainly restricted 
to the observation of fetal-heart-rate-patterns. The methods used are fetal phono- or electrocardiography and the ultrasonic Doppler-signal. Other useful parameters are in some cases amnioscopy, and during long-time application continous measurement of oestriol- and human placental lactogen concentrations, together with ultrasound cephalometry. Some investigators have admin istered tocolytics during an advanced stage of parturition and collected micro-blood-specimens from the presenting part for blood-gas-analysis. In other cases newborns were examined following failure of tocolytic therapy.

\section{Cardiovascular effects}

In the concentrations essential for tocolytic efficiency all the adrenergic $\beta$-mimetic compounds affect the cardiovascular system, occasionally to a significant degree, thus limiting their clinical usefulness. The maternal hypotensive and cardioaccelatory effects associated with the use of $\beta$-mimetic tocolytics have been emphasized by many authors $[4,5,6,7,8,11,12$, $16,28,29,31,36,39,43,45,46,49,54,57,58,63$, $66,67,68,69,72]$.

Additional administration of Iproveratril has proved to be efficient in reducing the maternal cardiovascular side effects. Moreover this compound may act synergistically with the $\beta$-mimetics in inhibiting uterine activity $[42,43,49,52,64]$.

\subsection{Influence upon fetal circulation}

The influence of $\beta$-mimetic catecholamines upon the fetal circulation has been reviewed by Eskes and DE HAAN recently [21]. Usually the fetal heart rate increases during infusion of $\beta$ mimetics $[10,21,29,31,45,57,62,67]$. During infusion of $0.05-0.2 \mathrm{mg}$ Ritodrine/min, however, some authors found no significant acceleration of the fetal heart rate $[5,8,66]$, even when maternal tachycardia was significant [36]. Also with Ritodrine concentrations as high as $0.38 \mathrm{mg} / \mathrm{min}$ the fetal heart rate remained within the limits of normal values, while a moderate acceleration in maternal heart rate from 70 to 105 beats/min was significant [11]. With Orciprenaline $(0.02-0.04 \mathrm{mg} / \mathrm{min}$ i. v.) a moderate increase of the fetal heart rate appeared $30 \mathrm{~min}$ after start of infusion [72]. When $0.1-0.6 \mathrm{mg} /$ min $\mathrm{Du} 21220$ were given intravenously during parturition, the increase of maternal heart rate was dose-dependent. The fetal heart rate acceleration, however, did not display this relationship [25]. With $1.5-3.0 \mu \mathrm{g} / \mathrm{min} \mathrm{Th}$ $1165 \mathrm{a}$ i. v. a fetal tachycardia of $+3 \%$ was observed, which in contrast to the mother started later and reached a maximum of $+5 \%$ when the infusion had already ended [29].

According to these results, fetal heart rate acceleration during administration of $\beta$ mimetic tocolytics is independent of maternal tachycardia. The fetal tachycardia presumably indicates that tocolytic agents, having crossed the placenta, directly stimulate the $\beta$-receptors in the fetal myocardium [31, 57, 72].

EsKES and DE HAAN [21] studied six aspects of fetal heart rate by a method of computer evaluation. The $\beta$-mimetic catecholamines did not influence the patterns of short-time irregularity, except when the basal heart frequency increased to over 150 beats/min.

No changes of the fetal electrocardiogram were observed by several authors using Isoxsuprine $[6,56,57]$.

\subsection{Infusion of $\beta$-mimetric in lateral position}

Maternal cardiovascular reaction to tocolytic $\beta$-mimetic drugs, however, can have a profound influence on the fetal circulation, when severe maternal hypotension occurs [21]. During infusion of $\beta$-mimetics in the supine position, a breakdown of the uteroplacental bloodflow with its detrimental effects on the fetus results from a supine hypotensive syndiome [19, 29, 57]. CRAWFORD [15] noted that frequently a decreased venous return is compensated for a time by vasoconstriction. In those cases $\beta$-stimulated peripheral vasodilatation may antagonize this endogenous compensation, endangering the uteroplacental blood-flow. Therefore a lateral position during infusion of $\beta$-mimetic tocolytics is generally recommended.

\subsection{Failure of the placental respiratory func- tion}

On the other hand, $\beta$-stimulated peripheral vasodilatation together with a wider pulse 
amplitude, resulting from unchanged systolic blood pressure when the diastolic tension is lowered [69], and an increased maternal cardiac output consequently enhance placental perfusion, improving the oxygen supply to the fetus. This is especially the case when this effect is additional to the desired relaxation of the uterus. When chronic placental insufficiency exists, normal labor contractions and especially hyperactive contractions are likely to produce an acute failure of the placental respiratory function. Diminution of frequency and intensity of uterine contractions, as well as reduction of the uterine basal tonus by tocolytics interfere with the pathophysiological mechanisms of acute placental insufficiency [50]. Gamissans, Esteban-AltirRIBA and MAIQUES [25] observed in their series of sub partu Ritodrine-treated patients two cases with a fetal capillary $\mathrm{pH}$ of 7.18 and 7.22 respectively. The cardiotocogram displayed late decelerations. When uterine activity decreased during administration of Ritodrine, the late decelerations disappeared and the fetal $\mathrm{pH}$ rose to 7.24 and 7.27 respectively. In 4 other patient's fetal $\mathrm{pH}$-values increased within normal ranges after inhibition of uterine activity. In further investigations these authors studied the usefulness of intravenous infusion of tocolytics for the treatment of intra partum fetal acidosis. In most of their patients they were able to achieve a significant rise of former acidotic or preacidotic fetal capillary $\mathrm{pH}$ values together with the inhibition of labor contractions. Fetal $\mathrm{PCO}_{2}$ decreased in cases of respiratory and mixed acidosis, and tended to increase when metabolic acidosis prevailed [26]. According to their results with a group of another 41 cases of suspected intra partum fetal acidosis due to uterine hyperactivity or cord compression, they now recommend a $\mathbf{1 5}$ minute-treatment trial with tocolytic infusion, before the fetus is delivered [22].

KüNZEL and REINECKE during $20 \mathrm{~min}$ infusion of $0.03 \mu \mathrm{g} \mathrm{Th} 1165 \mathrm{a} / \mathrm{min} / \mathrm{kg}$ body weight intra partum found an increase of fetal capillary blood $\mathrm{Po}_{2}$ from 15.6 to $18.2 \mathrm{~mm} \mathrm{Hg}$. Fetal oxygen saturation was elevated from 31.5 to $38.4 \%, \mathrm{pH}$ and $\mathrm{PCO}_{2}$ remained unchanged. These results, corresponding to an increase of fetal capillary blood oxygen concentration of $1.5 \mathrm{ml} / 100 \mathrm{ml}$ were supposed to be due to better uterine perfusion during $\beta$-mimetic replaxation of the uterus [35].

\section{$4.4 \beta$-mimetics in EPH-gestosis}

VAHRSON and SCHWARZ [63] reported 12 cases of severe EPH-gestosis where a reduction of systolic and diastolic hypertension was brought about by intravenous infusion of Buphenin without impairing the oxygen supply to the fetus.

Normalization of hypertension, increased uteroplacental blood-flow by peripheral vasodilatation with improved intrauterine conditions for the dysmature and placentalinsufficiency-endangered fetus are the basis for therapeutic long-time trials in EPH-gestosis [42]. This mode of action may also explain some authors' observations of increased biparietal diameters and higher birth-weights following long-time administration of $\beta$-mimetics $[29,49$, 52].

\section{Effects upon carbohydrate and fat metabolism}

Another interpretation of possibly increased fetal growth during tocolytic long-time therapy may be given by continuously elevated maternal blood glucose levels, resulting from $\beta$-mimetic effects upon carbohydrate metabolism. Contrast to the well known and thoroughly studied maternal cardiovascular alterations caused by $\beta$ mimetic tocolytics, the metabolic effects of the compounds used have not been sufficiently noticed until recently. Jung, Abramowski, KLÖCK and SCHwENZEL [31] reported an immediate severe increase of blood glucose concentrations, together with glycosuria and ketonuria in a pregnant diabetic during tocolytic treatment. LIPPERT, KUBLI and RÜTTGERS [38] demonstrated the hyperglycemic activity of Isoxsuprine and Buphenin in pregnant women. 60 minutes after the intramuscular injection of $5 \mathrm{mg}$ Buphenin the blood glucose concentration had risen to $150 \%$ of the starting level. $10 \mathrm{mg}$ Isoxsuprine, however, caused only a non-significant increase of $8.6 \%$. They also found marked hyperglycemia, glycosuria and aceton- 
uria following administration of Isoxsuprine or Buphenin to diabetic pregnant women.

More detailed examinations of $\beta$-mimetic effects upon carbohydrate and fat metabolism during tocolytic therapy have been reported lately by some groups of investigators. During oral, intramuscular or intravenous application of Dilatol or $\mathrm{Th} 1165 \mathrm{a}$ maternal blood glucose levels increased $10-40 \%$ above the starting level; when Dilatol is infused intravenously, maternal glucose concentration doubled immediately [55]. $50-260 \mu \mathrm{g}$ (average $90 \mu \mathrm{g}$ ) Dylidrin/min i. v. caused an increase of maternal glucose from 82 to $140 \mathrm{mg} / 100 \mathrm{ml}$ [51]. At the time, $1 \mu \mathrm{g} \mathrm{Th}$ $1165 \mathrm{a} / \mathrm{min}$ is infused for $24-48 \mathrm{hrs}$, and daily variations in blood glucose concentrations are likewise elevated [37].

After $5 \mathrm{mg}$ Th 1165 had been given orally, pregnant women without uterine contractions reacted with an average increase of $40 \mathrm{mg} / 100 \mathrm{ml}$ in blood glucose within $90 \mathrm{~min}$. Another $90 \mathrm{~min}$ later, glucose levels had normalized [64]. Pathologic high blood glucose concentrations were found following an oral glucose load of $50 \mathrm{~g}$ during Dilatol- or Th 1165a therapy [55]. Glucose assimilation has been found unchanged by some [64], others, however, have reported an impairment of glucose assimilation following a combined insulin-glucose-tolerance test during tocolytic therapy [37]. After oral administration of $5 \mathrm{mg}$ Th $1165 \mathrm{a}$ maternal insulin concentrations were found increased, following the rise of glucose concentrations with a short time-lag [64]. During long-time application other authors determined rather low levels of maternal insulin concentrations [37]. When $3 \mu \mathrm{g}$ Th $1165 \mathrm{a} / \mathrm{min}$ were infused intravenously for 4 hours in a homogeneous group of normal healthy pregnant women at term, not in labor and having fasted for 8 hours, blood glucose concentrations showed a continous rise which became significant after $60 \mathrm{~min}$. A the same time the insulin concentrations were 5 times higher than the starting levels and decreased slightly in the following 3 hours. Free fatty acids and free glycerol concentrations doubled, lactate and pyruvate concentrations rose continously, reaching levels 3 times higher than at the start of the infusion. Acetoacetate and $\beta$-hydroxybutyrate concentrations rose immediately when the $\beta$-mimetic was infused. Having reached a $2-2.5$ fold increase, beginning from the second hour, acetoacetate and $\beta$-hydroxybutyrate declined slowly, free fatty acids and free glycerol acted in the same way, while the concentrations of neutral fats, total glycerol and esterified glycerol were changed at first, showing an increase from the second hour until the end of the infusion. Within $60 \mathrm{~min}$ after the end of the infusion, nearly all the changes of metabolite concentrations had normalized with the exception of the pyruvate and lactate levels $[14,61,62]$.

$15 \mathrm{~min}$ after starting an infusion of $0.12 \mathrm{mg}$ TV $399 / \mathrm{min}$ in pregnancies at term without uterine contractions, maternal lactate concentrations increased from 11.51 to $24.94 \mathrm{mg} / 100 \mathrm{ml}$, the pyruvate concentrations rose from 0.256 to $0.392 \mathrm{mg} / 100 \mathrm{ml}$. Maternal actual $\mathrm{pH}$ values appeared to be rather on the acid side [45]. Also WOLFF [70] reported a decrease in maternal base excess and actual $\mathrm{pH}$, still within normal ranges, $15 \mathrm{~min}$ after the end of a $60 \mathrm{~min}$ infusion of $0.17 \mathrm{mg}$ Dilatol/min.

During infusion of $2 \mu \mathrm{g}$ Th $1165 \mathrm{a} / \mathrm{min}$ at the beginning of the first stage of labor, maternal actual $\mathrm{pH}$, as well as base excess decreased significantly, $\mathrm{Po}_{2}$ and $\mathrm{Pco}_{2}$ underwent no significant changes [33]. When $0.1 \mathrm{mg}$ Buphenin/min is used under similar conditions, maternal acidbase parameters remain unchanged $[33,51]$.

\subsection{Potassium concentration during infusion of $\beta$-mimetics}

Another response typical for $\beta$-mimetic compounds is a decrease in plasma potassium concentrations, resulting from a shift in the intracellular - extracellular potassium balance [23, 40]. During infusion of $3 \mu \mathrm{g}$ Th $1165 \mathrm{a} / \mathrm{min}$ a highly significant rapid fall of potassium concentrations in maternal serum was found, reaching levels as low as $2.8 \mathrm{mval} / \mathrm{l} .60 \mathrm{~min}$ after the end of the infusion the potassium concentrations had recovered [61, 62]. 


\subsection{Changes in maternal metabolism}

Summarizing these corresponding results, it can be concluded that immediately after starting a tocolytic therapy by an infusion of $\beta$-mimetic agents lipolysis and glycogenolysis are triggered off. The glycogen reserves are mobilized. High lactate levels are mainly evidence of hydrolysis of muscle glycogen. Acute lipolytic mobilizing of fat reserves causes increases of free fatty acids, the high concentrations of which evidently block the metabolizing of acetyl-co-A, thus leading to excessive high levels of ketone bodies. After this has continued for some time, however, compensating mechanisms come into force. Increased insulin levels following elevated glucose concentrations support glucose assimilation. In addition, increased lactate concentrations may flow into gluconeogenesis. Resynthesis of neutral fats is enhanced, ketone body concentrations decrease, and the acute alterations balance.

The changes in maternal acid-base parameters, which indicate an acute metabolic acidosis during infusion of $\beta$-mimetic tocolytics concur well with these findings. After inhibition of uterine contractions in the first stage of labor by infusion of $0.1 \mathrm{mg} \mathrm{TV} 399 / \mathrm{min}$ or $2.5 \mu \mathrm{g} \mathrm{Th}$ $1165 \mathrm{a} / \mathrm{min}$ actual $\mathrm{pH}$ values from fetal scalp capillary blood were found to be within normal ranges [31]. When maternal base excess and $\mathrm{pH}$ decreased during infusion of Dilatol, these parameters changed in the way in the capillary blood [70]. During infusion of $2 \mu \mathrm{g}$ Th 1165a/ min, in accordance with maternal changes, fetal actual $\mathrm{pH}$ and base excess were significantly lowered, whereas $\mathrm{Po}_{2}$ and $\mathrm{Pco}_{2}$ remained unaltered [33]. Maternal hyperglycemia during infusion of Dilydrin is rapidly reflected in the fetus [51]. Fetal $\mathrm{pH}$ values are within the normal range in the umbilical artery; however, there is a tendency for them to decrease; $\mathrm{Pco}_{2}, \mathrm{Po}_{2}$ and $\mathrm{O}_{2}$-saturation display no alterations [51]. Rises of maternal lactate and pyruvate concentrations during infusion of TV 399 were consistent with an increase of fetal lactate and pyruvate concentrations, while $\mathrm{pH}$ and base excess decreased [45]. There can be no doubt that small molecules like glucose, lactate, pyruvate, acetoacetate and $\beta$ - hydroxybutyrate readily pass across the placenta into the fetal organism. Maternal high concentrations of acid metabolites are most likely to produce a fetal metabolic acidosis. In contrast to glucose and low-molecular acids, free fatty acids are bound to albumin and cannot pass across the placenta [74].

\section{Placental transfer and metabolism of catecholamines}

Catecholamines do cross the placental membranes in humans. When ${ }^{14} \mathrm{C}$-labelled norepinephrine was injected into the mother before birth of non-viable fetuses, appreciable amounts of radioactivity were recovered from umbilical cord- and fetal heart blood [53]. ZuSPAN, WHALEY, Nelson and Ahrquist [74] concluded from the high increase of glucose concentrations in fetal blood following epinephrine infusion to the mother, that sufficient epinephrine had passed across the placenta to induce additional glucose mobilization in the fetus. Morgan, SANDLER and PANigel [41] were able to demonstrate a rapid transfer of the catecholamines norepinephrine and isoproterenol from the maternal to the fetal side in perfused human placentas in vitro.

\subsection{Placental enzymes}

During the placental passage, however, the catecholamines to some extent undergo metabolization and inactivation. Placental tissues contain rather high activities of the two main catecholamine degrading enzymes: monoamine oxidase and catechol-O-methyl transfèrase [13, 41, 60]. The placental monoamine oxidase, like the enzymes in the liver, kidney and elsewhere can oxidize a number of aromatic monoamines, but is inactive against diamines like histamine. Again like the liver enzyme, the activity of the placental enzyme is proportional to the oxygen tension of the medium in which it acts [60]. Macroscopic regressive altered placental tissue metabolizes less ${ }^{3} \mathrm{H}$-norepinephrine than normal tissue [13]. Catechol-O-methyl transferase of placental tissue was also shown to be able to catalyze O-methylation of isoproterenol, a typical $\beta$-mimetic catecholamine derivative [41].

From these results it can be presumed that these placental enzymes play a role in defending the 
fetus from the damaging access of catecholamines into its circulation [41].

Also uterine tissue contains both the enzyme activities [13, 60]. Moreover, the fetus and newborn themselves appear to be equipped with the two key catecholamine degrading enzymes in their own right $[17,48]$. Catechol-O-methyl transferase is found in human liver before birth, and its activity increases with age [1]. In livers of fetuses at the $3 \mathrm{rd}-4$ th month of gestation, high activities of monoamine oxidase and catechol-Omethyl transferase are present. Brain and heart tissues contain catechol-O-methyl transferase but less monoamine oxidase activities [13]. The authors $[1,13]$ suggest that in an early state in fetal tissues catecholamines are mainly degraded by catechol-O-methyl transferase, monoamine oxidase gaining importance later.

In a case of phaeochromocytoma in pregnancy, distinctly lower catecholamine concentrations were observed in umbilical blood than in maternal blood, presumably due to vigorous inactivation [59]. Increased induction of the catecholamine metabolizing enzymes by the continous high substrate supply may be discussed in such cases.

\subsection{Changes in fetal metabolism}

According to the results described above, it has to be taken into consideration that during $\beta$ mimetic tocolytic therapy glycogenolysis and lipolysis occur in the mother as well as in the fetus. If after $2-3$ hours of $\beta$-mimetic tocolytic infusion the therapy fails, a metabolic acidosis, resulting from increased concentrations of acid metabolites: lactate, acetoacetate, $\beta$ hydroxybutyrate in the fetus has to be anticipated.
The glycogen reserves may be depleted, and fetal hypoglycemia is subsequently endangering the newborn. After a longer-lasting therapy, however, the initial $\beta$-stimulated metabolic changes have balanced out and arelikely to be of less importance.

A first report on 51 children, born after longtime tocolysis with Th $1165 \mathrm{a}$, who were thoroughly followed up biochemically and neurologically to the age of 18 months did not reveal any impairments [65].

Recent results indicate that Estriol- and HPLconcentrations may have a tendency to increase of less than the normal rate during long-time $\beta$-mimetic therapy, though growth of the fetal biparietal diameter is regular at the same time [27].

4 cases of sudden intrauterine death during tocolytic therapy have been reported $[4,47,62]$. In 3 of these stillbirths regressive changes and fibrocalcific deposits were found in the placenta.

Recently ZLATNIK [73] emphasized that labor inhibition is applicable only to a minority of patients with impending premature births, thus reducing over-optimistic expectations. In addition to regarding the well-outlined contraindications of tocolytic therapy, an assessment of the fetal condition has to be conducted. When faulty intrauterine environments exist because of poor maternal nutrition, reduced uterine blood-flow, chronic maternal disease, a pre-term delivery under careful monitoring would be more suitable than an useless prolongation of the pregnancy.

\section{Summary}

$\beta$-Mimetic catecholamines have been proved useful in the treatment of threatening premature births (Tab. I). The fetalneonatal effects of the substances used have been evaluated rather poorly until recently. Adrenergic $\beta$ stimulation releases a complex of different responses, of which the relaxation of uterine muscle is only one component. Other important $\beta$-stimulated effects are cardioaccelatory, vasodilatory and hypotensive as well as glycogenolytic and lipolytic reactions. The evaluation of influences on the fetus, associated with $\beta$-mimetic tocolysis has to take into consideration the whole pattern of $\beta$-stimulated cardiovascular and metabolic responses.
The fetus is involved in two ways: 1 . The maternal cardiovascular and metabolic alterations affect the fetus indirectly, 2. The tocolytic agent is transferred across the placenta and is triggering the same responses in the fetal organism itself. Maternal hypotension, induced by tocolysis can have detrimental consequences for the fetus, especially when a supine hypotensive syndrome is favoured and the utero-placental blood-flow collapses. A lateral position during infusion of $\beta$-mimetic tocolytics is recommended. On the other hand, $\beta$-stimulated peripheral vasodilatation, together with a wider pulse amplitude, which results from unchanged systolic blood pressure when the 
diastolic tension is lowered, and an increased maternal cardiac output, consequently enhance placental perfusion, improving the oxygen supply to the fetus. In particular this is the case, when this effect is additional to the desired relaxation of the uterus, or when a chronic placental insufficiency exists.

Higher birth-weight after long-time administration of tocolytic $\beta$-mimetics may be explained by better uteroplacental circulation, and or by increased blood glucose levels. Immediately after starting a tocolytic infusion of $\beta$-mimetics, lipolysis and glycogenolysis are triggered. The glycogen depots are mobilized. High lactate levels indicate preferred hydrolysis of muscle glycogen. Acute lipolytic mobilizing of neutral fat depots causes increase of free fatty acids, the high concentrations of which evidently block the metabolizing of acetyl-co-A, thus leading to excessive high levels of ketone-bodies. Subsequently, however, compensating regulations are commencing: Increased insulin levels following elevated glucose concentrations support glucose assimilation; increased lactate concentrations may flow into gluconeogenesis. Resynthesis of neutral fats is enhanced, ketoacid concentrations decrease. In good coincidence with these findings are the changes in maternal acid-baseparameters, which indicate an acute metabolic acidosis during infusion of $\beta$-mimetic tocolytics.

There can be no doubt, that small molecules, like glucose, lactate, pyruvate, acetoacetate and $\beta$-hydroxybutyrate readily pass across the placental membranes into the fetal organism. Maternal high concentrations of acid metab- olites are most likely to produce a fetal metabolic acidosis. Catecholamines and catecholamine derivatives themselves do cross the placenta in humans and additionally induce the typical $\beta$-stimulated responses in the fetal organism itself. In placental and fetal tissues $\beta$ mimetic catecholamines are likely to be metabolized. The two catecholamine degrading enzyme activities monoamine oxidase and catechol-O-methyl transferase have been identified in placental and fetal tissues, so that to some extent inactivation and protection may be possible. In the practical use it has to be realized, that during $\beta$-mimetic tocolytic therapy glycogenolysis and lipolysis occur in the mother as well as in the fetus. When after $2-3$ hours of $\beta$-mimetic tocolytic infusion the therapy fails, a metabolic acidosis, resulting from ingreased concentrations of acid metabolites: lactate, acetoacetate, $\beta$-hydroxybutyrate has to be anticipated in the newborn. The glycogen depots may be depleted and hypoglycemia is endangering the newborn. After long-time therapy, however, the initial $\beta$-stimulated metabolic changes have balanced and are likely to be of less importance. Infants followed up biochemically and neurologically for 18 months after tocolytic therapy did not display any signs of impairment.

Before starting a tocolytic therapy, fetal condition should be evaluated carefully. In cases of severe reduction of placental function, a preterm delivery may be more favourable to the fetus than any prolongation of the pathologic pregnancy.

Keywords: Acidosis (metabolic), catecholamines ( $\beta$-mimetic), glycogenolysis, labor (premature), lipolysis, supine hypotensive syndrom, tocolysis.

\section{Zusammenfassung}

Einfluß von sympathicomimetischen tokolytischen Substanzen auf den Feten

Die Ruhigstellung der Uterusmuskulatur durch Stimulierung der $\beta$-adrenergen Rezeptoren im Myometrium findet als symptomatische Therapie vorzeitiger und hyperaktiver Uteruskontraktionen zunehmend Anwendung (Tab. I). Dabei stellt die relaxierende Wirkung auf die Uterusmuskulatur nur eine Komponente aus dem Gesamtkomplex der $\beta$-stimulierten Reizbeantwortung dar. Die Beurteilung möglicher Nebenwirkungen auf den Feten hat aber das vollständige Spektrum $\operatorname{der} \beta$-stimulierten Veränderungen $\mathrm{zu}$ berücksichtigen, das neben kardioakzeleratorischen und vasodilatatorischen Wirkungen als typische, über die Bildung von zyklischem $3^{\prime}-5^{\prime}$ Adenosinmonophosphat induzierte metabolische Veränderungen auch eine Glykogenolyse und Lipolyse umfaßt.

Der Fet kann in dem zunächst bei der Mutter durch die tokolytische Therapie ausgelösten Reaktionsablauf einmal indirekt über die kardiovaskulären und metabolischen Alterationen des mütterlichen Organismus einbezogen werden, zum anderen können nach diaplazentarem Übertritt $\operatorname{der} \beta$-mimetischen Substanz in den fetalen Organismus dort selbst die gleichen Reaktionen stimuliert werden.
Die mütterliche Tachykardie allein ist für den Feten ohne wesentliche Bedeutung. Durch $\beta$-Stimulation induzierte mütterliche periphere Vasodilatation und Hypotonie können aber, insbesondere bei hypotoner Ausgangssituation $\mathrm{zu}$ einer verminderten Durchblutung von Uterus und Plazenta, zur Beeinträchtigung der Sauerstoffversorgung und damit zur akuten respiratorischen $\mathrm{Pla}$ zentainsuffizienz führen. Diese Situation kann sich vor allem auch ergeben, wenn durch tokolytische Infusion in Rückenlage ein Vena-cava-Syndrom begünstigt wird. Andererseits kann jedoch die periphere Vasodilatation auch zu verbesserter uteroplazentarer Durchblutung führen, vor allem wenn diese Wirkung zusätzlich zu einer angestrebten Ruhigstellung des Uterus hinzutritt. Auf diese Weise kann möglicherweise die Versorgung des Feten intrauterin unter der Geburt und auch durch Langzeittherapie bei EPH-Gestose verbessert werden.

Die typișchen $\beta$-stimulierten Stoffwechselveränderungen haben erst in jüngerer Zeit eingehendere Untersuchung erfahren. Unter akuter tokolytischer Infusionstherapie kommt es rasch zur Glykogenolyse, wobei vorwiegend Muskelglykoyen gespalten wird, mit deutlichem Anstieg der Konzentrationen von Laktat, Pyruvat und Glukose im mütterlichen Blut; gleichzeitig erfolgt eine massive 
Insulininkretion. Ebenso rasch setzt die Lipolyse ein, aus der ansteigende Konzentrationen von freien Fettsäuren, freiem Glycerin, aber auch durch die Hemmung der Metabolisierung von Azetyl-Co-A, von Ketonkörpern wie Azetessigsäure und $\beta$-Hydroxybuttersäure resultieren. Nach etwa 2 bis 3 Stunden tokolytischer Infusion beginnen sich diese Veränderungen zum Teil einzupendeln und wieder auszugleichen: Die Resynthese von Neutralfetten setzt ein und die Ketonkörperkonzentrationen bilden sich zurück. Nach der beim Feten und Neugeborenen nachgewiesenen Tendenz der aktuellen $\mathrm{pH}$-Werte zum sauren Bereich, ebenso wie der Abnahme des Basenexcess' und die Zunahme der Konzentrationen von Laktat und Pyruvat muß angenommen werden, $\mathrm{da} \beta$ die niedermolekularen Metabolite unmittelbar diaplazentar übergehen und auch beim Fet, wie bei der Mutter zu einer metabolischen Azidose beitragen. Diese Stoffwechselveränderungen müssen berücksichtigt werden, falls ein Kind in dieser akuten Phase tokolytischcr Infusionstherapie geboren wird, zum Beispiel nach Versagen eines Tokolyseversuchs. Nach Langzeittherapie treten die Veränderungen im Kohlenhydrat- und Fettstoff wechsel wegen der ausgleichenden Regulationen in ihrer Bedeutung zurück. Die nach Langzeittherapie mit $\beta$-mimetischen Tokolytica vereinzelt beobachteten erhöhten Geburtsgewichte können einerseits über das vermehrte Glukoseangebot, andererseits aber auch durch die verbesserte uteroplazentare Durchblutung gedeutet werden. Biochemische und neurologische Verlaufs- kontrollen und Nachuntersuchungen nach Langzeittherapie haben bisher bis zu einem Alter von 18 Monaten keinen Anhalt für tokolysebedingte Veränderungen oder Schädigungen ergeben.

Der diaplazentare Úbergang von $\beta$-mimetischen Katecholaminderivaten wie sie zur Tokolyse Anwendung finden ist erwiesen. $\mathrm{Zu}$ den durch die erhöhten mütterlichen Metabolitkonzentrationen induzierten Stoffwechselveränderungen beim Feten, treten nun die im fetalen Organismus selbst ausgelösten gesamten typischen $\beta$-stimulierten Effekte noch hinzu, so daß zum Beispiel bei unter oder nach Tokolyse geborenen Kindern mit verminderten Glykogendepots und der daraus resultierenden erhöhten Gefährdung durch eine post-partuale Hypoglykämie zu rechnen ist. In Plazentagewebe, wie auch in fetalen Organen liegen die Aktivitäten von Monoaminoxydase und Katechol-O-methyltransferase, den Schlüsselenzymen von Inaktivierung und Abbau von Katecholaminen vor, so daß eine gewisse Limitierung der Katecholaminwirkung gegeben sein kann.

Bei Vorliegen ungünstiger intrauteriner Bedingungen für den Feten, wie zum Beispiel durch chronische Plazentarinsuffizienz sollte vor Beginn einer tokolytischen Therapie mittels umfassender Diagnostik geprüft und abgewogen werden, ob eine frühzeitige Entbindung unter Intensivüberwachung nicht günstigere Chancen für das dysmature Kind bedeutet als eine Verlängerung der pathologischen Schwangerschaft.

Schlüsselworte: Azidose (metabolische), Glykogenolyse, Katecholamine ( $\beta$-mimetische), Lipolyse, Tokolyse, Venacava-Syndrom, Wehen (vorzeitig).

\section{Résumé}

Effects des agents sympathicomimetiques sur le foetus

Les catécholamines $\beta$-mimétiques ont fait la preuve de leur utilité dans le traitement des menaces d'accouchement prématuré (tab. I). Jusqu'il y a peu de temps, les effets foetaux et néo-nataux de ces substances avaient été étudiés de façon très sommaire. La stimulation des fibres $\beta$-produit différents phénomènes, la relaxation utérine en est un parmi tant d'autres. Des effets également importants de cette activité sont la tachycardie, la vasodilatation, l'hypotension, ainsi que le glycogénolyse et al lipolyse. Si on veut étudier l'influence de la relaxation utérine par les $\beta$-mimétiques, il faut tenir compte de toutes les formes de réaction, tant cardiovasculaires que métaboliques, du foetus à la stimulation $\beta$.

Les $\beta$-mimétiques agissent de deux façons sur le foetus:

$1^{\circ}$ de façon indirecte, par leur action sur l'état cardiovasculaire et le métabolisme de la mère.

$2^{\circ}$ directement, l'agent myorelaxant traverse le placenta et produit ces effets chez le foetus.

L'hypotension maternelle, engendrée par la relaxation utérine, peut avoir des conséquences funestes pour le foetus, principalement, lorsque apparait une hypotension de décubitus, et une chute du débit utéroplacentaire. Il est donc préférable de placer la patiente en décubitus latéral pendant l'administration de $\beta$-mimétiques.

D'un autre côté, il se produit une vasodilatation périphérique associée à une augmentation de l'amplitude du pouls dues au fait que la pression artérielle systolique reste inchangée lorsque la diastolique s'abaisse; ceci provoque une élivation du débit cardiaque maternel et par voie de conséquence une augmentation de la perfusion placentaire et de l'apport d'oxygène au foetus. C'est en particulier le cas, lorsqu'il existe une insuffisance chronique placentaire.

L'élivation du poids de naissance observée après administration de longue durée de $\beta$-mimétiques peut s'expliquer par l'amélioration de la circulation utéro-placentaire, ou par l'augmentation de la glycémie ou par les deux à le fois.

Dès le début d'une perfusion de $\beta$-mimétiques apparaissent de phénomènes de lypolyse et de glycogénolyse. Les dépôts de glycogène, surtout musculaires, sont mobilisés, ce qui se traduit par une élévation des taux de lactate. La lipolyse borsque en mobilisant les dépôts de graisse neutre, provoque une augmentation des acides 
gras libres. La concentration élevée de ceux-ci bloque le métabolisme de l'acétyl co-enzyme $A$, et aboutit à la production excessive de corps cétoniques. Cependant, des mécanismes compensateurs se mettent en action immédiatement. L'élévation de la glycémia entraine une augmentation des taux d'insuline; la concentration élevée en lactate provoque une gluconéogenèse. Il y a resynthèse des graisses neutres et diminution des corps cétoniques. Ces faits sont confirmés par l'étude des paramètres de l'équilibre acido-basique maternel, qui montrent l'existence d'une acidose métabolique aigue pendant le perfusion des $\beta$-mimétiques.

Il n'est pas douteux que les petités molécules, telles que glucose, lactate, pyruvate, acéto-acétate et $\beta$-hydroxibutyrate traversent rapidement la barrière placentaire. La concentration élevée de ces métabolites acides dans le sang maternel provoque évidemment une acidose métabolique foetale. Les catécholamines et leurs dérivés traversent le placenta humain et produisent leurs effets $\beta$-mimétiques directement sur le foetus. Les $\beta$-stimulants sont vraissemblablement métabolisés par le placenta et les tissus foetaux. Deux enzymes nécessaires au catabolisme des $\beta$-mimétiques à savoir, la monoaminoxydase et la catéchol-o-méthyl trans férase ont été isolées du placenta et des tissus foetaux.
De cette façon, il semble que les $\beta$-stimulants soient inactivés dans l'organisme du foetus, et que celui-ci s'en protège jusqu'à un certain degré.

On doit bien s'imaginer qu'au cóurs d'une thérapeutique tocolytique par les $\beta$-mimétiques, la glycogénolyse et la lipolyse apparaissent tant chez la mère que chez le foetus. Lorsqu'on constate un échec de la thérapeutique après une perfusion de deux à trois heures de $\beta$-stimulants, l'acidose métabolique due à l'élévation des taux de métaboliques acides (lactate - acétoacétate - $\beta$-hydroxybutirate) doit étre prévue. Les réserves en glycogène peuvent être épuisées et on sait que l'hypoglycémie est dangereuse pour le foetus.

Au contraire, lors des thérapeutiques de longue durée, les modfications métaboliques initiales dues aux $\beta$-stimulants auront pu être neutralisées et présenteront alors une moindre importance. Les enfants étudiés du point de vue biochemique et neurologique jusqu'à 18 mois après thérapeutique tocolytique ne présentent aucun trouble.

Avant de commencer un traitament tocolytique, il faudra évaluer minutieusement létat de foetus, en cas de réduction sévère de la fonction placentaire, une naissance prématurée sera généralement préférable à la prolongation d'une grossesse pathologique.

Mots-clés: Acidose métabolique, $\beta$-mimétiques, glycogénolyse, lipolyse, hypotension de décubitus, tocolyse travail prématuré.

\section{Bibliography}

[1] Agathopoulos, A., D. Nicolopoulos, N. Matsanrotis, C. Papadatos: Biochemical changes of catechol-O-methyl transferase during development of human liver. Pediatrics 47 (1971) 125

[2] Ahlquist, R. P.: A study of the adrenotropic receptors Amer. J. Physiol. 153 (1948) 586

[3] Barden, T. P., R. W. Stander: Myometrial and cardiovascular effects of an adrenergic blocking drug in human pregnancy. Amer. J. Obstet. Gynec. 101 (1968) 91

[4] BARDEN, T. P.: Inhibition of human premature labor by Mesuprine hydrochloride. Obstet. Gynec. 37 (1971) 98

[5] BARDEN, T. P.: Effect of ritodrine on human uterine motility and cardiovascular responses in term labor and the early postpartum state. Amer. J. Obstet. Gynec. 112 (1972) 645

[6] Baumgarten, K.: Über die Inhibition der Uterusmotilität am graviden Organ. W. klin. Wschr. 80 (1968) 567

[7] Baumgarten, K., H. Fröhlich, A. Seidl, F. LimRachmat, K. SoKol: Über einen neuen intravenös anwendbaren Wehenhemmer ohne Kreislaufwirkung W. klin. Wschr. 81 (1969) 102

[8] Baumgarten, K., H. Fröhlich, A. Seidl, K. Sokol F. Lim-Rachmat, R. HAGER: A new $\beta$-sympathomimetic preparation for intravenous and oral inhibition of uterine contractions. Europ. J. Obstet. Gynec. 2 (1971) 69
[9] Baumgarten, K.: Klinische Erfahrungen mit dem Wehenhemmer Ritodrine. In: SALING, E., F. J. Schulte: Perinatale Medizin, Band II. 3. Deutscher Kongreß für Perinatale Medizin, Berlin 1970, Thieme, Stuttgart 1972

[10] Bertola, R. P., A. Marquez, A. O. Pan: Estudio de l'accion de la orciprenalina en obstetrica. Obstet. Ginec. Lat. Amer. 28 (1970) 255

[11] Bientarz, J., M. Motew, A.Scommegna: Uterine and cardiovascular effects of Ritodrine in premature labor. Obstet. Gynec. 40 (1972) 65

[12] Boden, W., H. v. D. CRABBEN: Wehenhemmung mit einer neuen $\beta$-adrenergen Substanz. Med. Welt 21 (1970) 1342

[13] Castren, O., S. SaArikoski: Die Metaboliten des ${ }^{3} \mathrm{H}-\mathrm{Nor}$-adrenalin in dem Homogenat von Placenta, Uterus und Menschenfötus. In: Navratil, E.: Vorträge u. wissenschaftl. Beitr. 5. Akad. Tagung dtschspr. Prof. u. Priv. Doz. f. Gebh. u. Gynäk. 1968. Thieme, Stuttgart 1971

[14] Conradt, A., V. Unbehaun: Lipolyse und Ketonämie während der Infusion von Th 1165a. In: DuDENhausen, J. W., E. Saling: Perinatale Medizin, Band IV. 5. Deutscher Kongreß für Perinatale Medizin Berlin 1972. Thieme, Stuttgart 1973

[15] Crawford, J. S.: Caesarean section and the anaesthesist. In: Bossart, H., J. M. Cruz, A. Huber, L. S. Prod'hom, J. Sistek: Perinatal Medicine. 3rd 
European Congress of Perinatal Medicine, Lausanne 1972. Huber, Bern-Stuttgart-Wien 1973

[16] Egcimann, U.: Dilydrin, ein $\beta$-Mimetikum als Wchenhemmer. Schweiz. Z. Gynäk. Geburtsh. 2 (1971) 209

[17] Epps, H. M. R.: The development of amine oxidase activity by human tissue. Biochem. J. 39 (1945) 37

[18] Eskes, T., L. Stolte, J. Seelen, H. D. Moed, C. VogelsaNG: Epinephrine derivates and the activity of the human uterus II. Amer. J. Obstet. Gynec. 92 (1965) 871

[19] Eskes, T. K. A. B.: Prevention and management of early labor. In: Huntingford, P. J., R. W. Beard, F. E. Hytten, J. W. Scopes: Perinatal Medicine. 2nd European Congress of Perinatal Medicine, London 1970. Karger, Basel-München-Paris-London-New York-Sidney 1971

[20] Eskes, T. K. A. B.: Vergleichende Untersuchungen zur Tokolyse mit $\beta$-Adrenergika. In: SALING, E., F. J. Schulte: Perinatale Medizin Band II. 3. 3. Deutscher Kongreß für Perinatale Medizin Berlin 1970. Thieme, Stuttgart 1972

[21] Eskes, T. K. A. B., J. DE HAaN: The influence of $\beta$-mimetic catecholamines upon the fetal circulation. Z. Geburtsh. Perinat. 176 (1972) 97

[22] Esteban-Altirriba, J., O. Gamissans, P. Duran, J. Calat, A. Rene: Administration of $\beta$-mimetic agents to the mother as a conservative therapy in cases of intrapartum fetal acidosis. In: SALING, E., J. W. Dudenhausen: Perinatale Medizin Band III. 4. Deutscher Kongreß für Perinatale Medizin Berlin 1971. Thieme, Stuttgart 1972

[23] Ferlinz, R., H. J. Stadeler, H. Schnitzler, U. RIck: Der Einfluß von Th 1165a (Berotec) auf Serum-Kalium und Blutzucker. Int. J. clin. Pharmacol. Beiheft 4 (1972) 59

[24] Fitzgerald, J. D.: $\beta$-adrenerge Stimulantien und Antagonisten. In: Kuemmerle, H. P., E. R. Garret, K. H. SpItzy: Klinische Pharmakologie und Pharmakotherapie. Urban \& Schwarzenberg, MünchenBerlin-Wien 1971

[25] Gamissans, O., J. Esteban-Altirriba, V. Maiques: Inhibition of human myometrical activity by a new $\beta$-adrenergic drug (Du-21220). J. Obstet. Gynaec. Brit. Cwlth. 76 (1969) 656

[26] Gamissans, O., J. Esteban-Altirriba, J. Calaf: The treatment of intrapartum fetal acidosis by intravenous infusion of $\beta$-adrenergic drugs to the mother. In: Huntingford, P. J., R. W. Beard, F. E. Hytren, J. W. Scopes: Perinatal Medicine. 2nd European Congress of Perinatal Medicine London 1970. Karger, Basel-München-Paris-London-New York-Sidney 1971

[27] Haller, U., D. Schenk, B. RúnNebaum, H. RütTGERS, U. LORENZ, F. KUBLI: Langzeitbehandlung mit Betamimetika während der Schwangerschaft und Verhalten von Oestriol. HPL und biparietalem Durchmesser. In: Dudenhausen, J. W., E. Saling: Perinatale Medizin Band IV. 5. Deutscher Kongreß für Perinatale Medizin Berlin 1972. Thieme, Stuttgart 1973
[28] HüTER, J.: Situationsgerechte Toko- und Tonolyse in der Geburtshilfe. Med. Welt 19 (1968) 2023

[29] Hüter, J., Ch. Rippert, C. Meyer: Wehenhemmung mit welchem $\beta$-Mimetikum (Berotec, Ritodrine, Dilatol)? Geburtsh. u. Frauenheilk. 32 (1972) 97

[30] JUNG, H.: Maintenance of pregnancy under the aspects of uterus-inhibiting substances. In: Grbian, H., E. Plotz: Mammalian Reproduction. Springer, Berlin-Heidelberg-New York 1970

[31] Jung, H., P. Abramowski, F. K. KlöcK, W. SChwENZEL: Zur Wirkung $\alpha$ - und $\beta$-adrenergischer Substanzen am menschlichen Uterus und Nebenwirkungen auf Mutter und Kind. Geburtsh. u. Frauenheilk. 31 (1971) 11

[32] Jung, H.: Zur Physiologie des Uterus-Muskels unter Berücksichtigung zellulärer und neuro-humoraler Regelvorgänge bei der Ruhigstellung des schwangeren Uterus. In: Saling, E., F. J. Schulte: Perinatale Medizin Band II. 3. Deutscher Kongreß für Perinatale Medizin Berlin 1970. Thieme, Stuttgart 1972

[33] Klöck, F. K., H. Chantraine, A. Etzrodt, B. Liedtke, H. J. Schulte: Der Einfluß des $\beta$-Stimulators $T h 1165 \mathrm{a}$ auf mütterliche und fetale Stoffwechsel-Parameter. In: Dudentausen, J. W., E. SALING: Perinatale Medizin Band IV. 5. Deutscher Kongreß für Perinatale Medizin Berlin 1972. Thieme, Stuttgart 1973

[34] Koepcke, E., G. Seidenschnur: Erfahrungen mit der medikamentösen Wehenhemmung. Dtsch. Ges.wesen 28 (1973) 546

[35] KüNzel, W., J. ReInecke: Der Einfluß von Th 1165 a auf die Gaspartialdrucke und auf kardiovaskuläre Parameter von Mutter und Fetus. Zugleich eine quantitative Analyse der Wehentätigkeit. Z. Geburtsh. Perinat. 177 (1973) 81

[36] Landesman, R., K. H. Wilson, E. M. Coutinho, J. M. KlIMA, R. S. MARcus: The relaxant action of ritodrine, a sympathomimetic amine, on the uterus during term labor. Amer. J. Obstet. Gynec. 110 (1971) 111

[37] Lang, N., O. Bellmann, H. Hrnckers, M. HansmanN, H. Schlebusch: Einfluß der Tokolytika auf den Kohlenhydratstoffwechsel. In: DudenHausen, J. W., E. Saling: Perinatale Medizin Band IV. 5. Deutscher Kongreß für Perinatale Medizin Berlin 1972. Thieme, Stuttgart 1973

[38] Lippert, T. H., F. Kubli, H. RüTtgers: Die hyperglykämische Aktivität von Tokolytika. Klin. Wschr. 50 (1972) 119

[39] Llixiona, J., L. Ferreres: La accion uteroinhibidora de un nuevo simpaticomimetico $\beta$-dervado de la orciprenalina, el Th 1165 a en obstetrica. Toko Ginec. Pract. 28 (1969) 763

[40] Man, N. K., P. Keller, W. Hallauer, J. SchirMEISTER: Die Hypokaliämie und Kaliurie nach intravenöser Gabe eines Symphathicomimetikums beim Menschen. Verh. Dtsch. Ges. Inn. Med. 73 (1967) 1045 
[41] Morgan, C. D., M. Sandler, M. Panigel: Placental transfer of catecholamines in vitro and in vivo. Amer. J. Obstet. Gynec. 112 (1972) 1068

[42] Mosler, K. H., H. G. Rosenboom: Neuere Möglichkeiten einer tokolytischen Behandlung in der Geburtshilfe. Z. Geburtsh. Perinat. 176 (1972) 85

[43] Mosler, K. H.: Potenzierung der Uterushemmung $\beta$-adrenerger Sympathomimetika durch neue kardioprotektive Substanzen. In: JuNG, H.: Methoden der pharmakologischen Geburtserleichterung und UterusRelaxation. Thieme, Stuttgart 1972

[44] Mosler, K. H.: Symptomatische Therapie der drohenden Frühgeburt. In: SAling, E., F. J. Schulte: Perinatale Medizin Band II. 3. Deutscher Kongreß für Perinatale Medizin, Berlin 1970. Thieme, Stuttgart 1972

[45] NEUBüSER, D.: Vergleichende Untersuchungen über zwei Tokolytika (TV 399 und Buphenin). Geburtsh. u. Frauenheilk. 32 (1972) 781

[46] NeumanN, H., U. Manteuffel: Behandlung der drohenden Fehl- und Frühgeburt mit Duvadilan. Zbl. Gynäk. 92 (1970) 1100

[47] Neumann, H., P. Hengst: Behandlung der drohenden Früh- und Fehlgeburt mit Dilatol. Zbl. Gynäk. 93 (1971) 849

[48] Nicolopoulos, D., A. Agathopoulos, C. Danelatou-Arhanassiadou, M. Bafatakr: Urinary excretion of phenolic and indolic compounds, metacatecholamines, and vanillinmandelic acid by full-term and premature infants. Pediatrics 41 (1968) 777

[49] Rippert, CFi., J. Hüter, R. Bärtschr: Intravenöse Langzeit-Wehenhemmung mit $\beta$-Mimetika und Antagonisierung der Nebenwirkungen. Geburtsh. u. Frauenheilk. 31 (1971) 710

[50] Rippert, Ch., J. Hüter, F. Kubli, C. Meyer: Medikamentöse Therapie der hyperaktiven, hyperonen und diskordanten Wehentätigkeit sub partu. Geburtsh. u. Frauenheilk. 32 (1972) 393

[51] Ruppen, M., J. Schmid: Der Einfluß kurzzeitiger Infusionen von Dylidrin auf den Säure-Basen-Haushalt und den Glukosestoffwechsel unter der Geburt. In: Dudenhausen, J. W., E. Saling: Perinatale Medizin Band IV. 5. Deutscher Kongreß für Perinatale Medizin Berlin 1972. Thieme, Stuttgart 1973

[52] Saling, E.: Prämaturitäts- und DysmaturitätsPräventionsprogramm (PDP-Programm). Z. Geburtsh. Perinat. 176 (1972) 70

[53] Sandler, M., C. R. J. Ruthyen, S. F. Contractor, C. Wood, R. T. Booth, J. H. M. Pinkerton: Transmission of noradrenaline across the human placenta. Nature 197 (1963) 598

[54] Schnell, J. D., H. Stockhausen: Tokographische Vergleichsuntersuchungen bei Anwendung verschiedener tokolytischer Substanzen. Arch. Gynäk. 211 (1971) 277

[55] Scholtes, G.: Blutzuckerverhalten bei der Behandlung mit den Wehenhemmern Büphenin (Dilatol) und Th 1165a. Z. Geburtsh. Perinat. 177 (1973) 90
[56] Shenker, L.: Effect of isoxsuprine on fetal heart rate and fetal electrocardiogram. Obstet. Gynec. 26 (1965) 104

[57] Stander, R. W., Barden; T. P., J. F. Thompson, W. R. Pugh, C. E. Werts: Fetal cardiac effects of maternal isoxsuprine infusion. Amer. J. Obstet. Gynec. 89 (1964) 792

[58] Stockhausen, H., J. Schnell, K. Rüther: Die Tokolyse unter der Geburt - eine tokographische Vergleichsuntersuchung bei Anwendung verschiedener tokolytischer Substanzen. Geburtsh. u. Frauenheilk. 32 (1972) 51

[59] Thiery, M., R. M. J. Derom, H. E. van Kets, A. F. de Schaepdryver, P. J. Bernard, S. A. C. Bekaert, C. M. J. Hooft, F. Derom, G. Rolly, H. J. R. RoEls: Phaeochromocytoma in pregnancy. Amer. J. Obstet. Gynec. 97 (1967) 21

[60] Thompson, R. H. S., A. Trckner: Observations on the mono-amine-oxidase activity of placenta and uterus. Biochem. J. 45 (1949) 125

[61] Unbehaun, V., A. Conradt, S. Hellek, H. Weber: Einfluß von Th $1165 \mathrm{a}$ auf die Konzentrationen von Glucose, Insulin, Kohlenhydratmetaboliten, Serumelektrolyten sowie humanem placentarem Lactogen. In: Dúdenhausen, J. W., E. Saling: Perinatale Medizin Band IV. 5. Deutscher Kongreß für Perinatale Medizin, Berlin 1972. Thieme, Stuttgart 1973

[62] Unbehaun, V., A. Conradt, E. Meiswinkel: Aspekte der Therapie drohender Frühgeburten. Med. Welt 23 (1972) 1920

[63] Vahrson, H., H. J. Schwarz: Zur Anwendung $\beta$ adrenergischer Substanzen in der Therapie schwerer Gestosen ohne Gefährdung des Kindes. Geburtsh. u. Fräuenheilk. 31 (1971) 536

[64] WeIdinger, H., D. MoHR: Blutglucose und immunreaktives Insulin unter dem Einfluß von Besopartin (Th 1165a, $\beta$-Sympathicomimeticum) und Isoptin bei Schwangeren mit und ohne tokolytische Therapie. In: Dudenhausen, J. W., E. Saling: Perinatale Medizin Band IV. 5. Deutscher Kongreß für Perinatale Medizin, Berlin 1972. Thieme, Stuttgart 1973

[65] Weidinger, H., W. Wiest, S. Dietze, K. Witzel: Die Auswirkungen langzeittiger Wehenhemmung auf das Neugeborene und den Säugling. In: Dudenhausen, J. W., E. Saling: Perinatale Medizin, Band IV. 5. Deutscher Kongreß für Perinatale Medizin, Berlin 1972. Thieme, Stuttgart 1973

[66] Weselius-de Casparis, A., M. Thieriy, A. Yo le Stan, K. Baumgarten, J. Brosens, O. Gamissans, J. G. Stolk, W. Viveri: Results of double-blind, multicentre study with Ritodrine in premature labour. Brit. Med. J. 3 (1971) 144

[67] Wolff, C. H.: Die medikamentöse Behandlung der vorzeitigen Wehentätigkeit. Z. Geburtsh. Gynäk. 167 (1967) 68

[68] WolfF, C. H.: Über die Behandlung der drohenden Frühgeburt mit Duvadilan. Geburtsh. u. Frauenheilk. 27 (1967) 402 
[69] Wol.fF, C. H.: Wirkung einer $\beta$-rezeptoren-stimulierenden Substanz (Buphenin) auf den Blutdruck normo- und hypertoner Frauen während der Schwangerschaft. Dtsch. med. Wschr. 95 (1970) 2332

[70] Wolff, C. H.: Fetale Begleitsymptomatik während der Dilatol-Dauertropfinfusion. Zbl. Gynäk. 92 (1970) 1307

[71] Wolff, C. H.: Synopsis der klinischen Erfahrungen mit Dilatol als Tokolyticum. In: Saling, E., F. J. Schulte: Perinatale Medizin, Band II. 3. Deutscher Kongreß für Perinatale Medizin Berlin 1970. Thieme, Stuttgart 1972

[72] Ziliantr, M., J. Aller: Action of orciprenaline on uterine contractility during labor, maternal cardio- vascular system, fetal heart rate, and acid base balance. Amer. J. Obstet. Gynec. 109 (1971) 1073

[73] ZlatNIK, F. J.: The applicability of labor inhibition to the problem of prematurity. Amer. J. Obstet. Gynec. 113 (1972) 704

[74] Zuspan, F. P., W. H. Whaley, G. H. Nelson, R. P. Ahlquist: Placental transfer of epinephrine. I. Maternal-fetal metabolic alterations of glucose and non esterified fatty acids. Amer. J. Obstet. Gynec. 95 (1966) 284

[75] Zuspan, F. P.: Premature Labor: Its management and therapy. J. Reprod. Med. 9 (1972) 93

PD Dr. Volker Unbehaun Universitäts-Frauenklinik Schleichstr. 4

D-74 Tübingen/Germany 